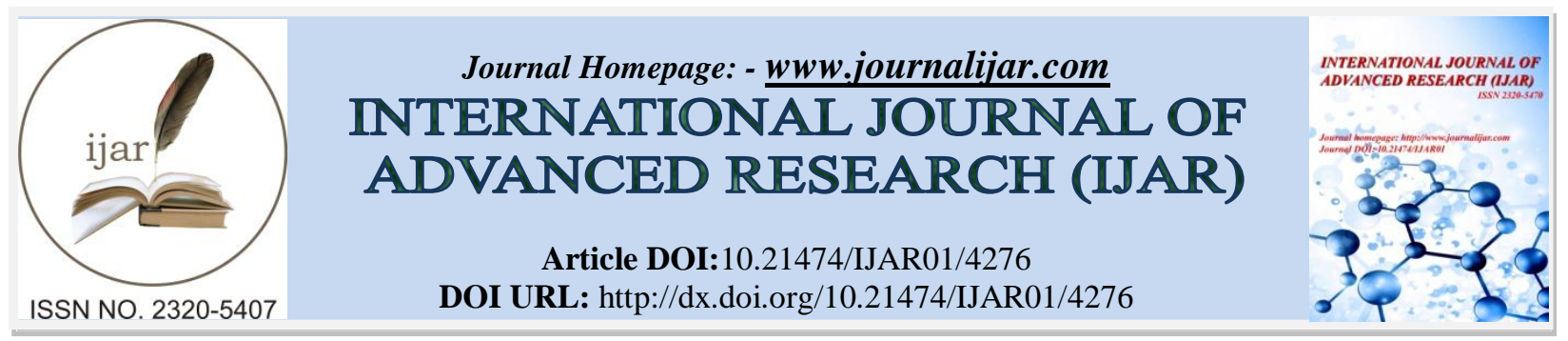

RESEARCH ARTICLE

\title{
A NEW DIAGNOSTIC METHOD TO DETECT BACTEREMIA TARGETING 23S AND 16S rRNA SEQUENCES BY STANDARD PCR
}

\author{
*Dr. K. Bramarambica ${ }^{1}$, Prof. Y. V. K. Durga Prasad ${ }^{2}$, B. Priyanka ${ }^{3}$ and Prof. S. Harasreeramulu ${ }^{4}$. \\ 1. Research Scholar Dept. of Biotechnology Dr.V.S.Krishna Govt. College(A), Affiliated to Andhra University. \\ 2. Research guide \& Director Centre for Research Studies.Dr.V.S.Krishna, Govt. College(A) Affiliated to Andhra \\ University. \\ 3. P.G. Dept of Biotechnology, Dr.V.S.KrishnaGovt.College(A). \\ 4. Dean Biotechnology A.P.IIIT-IdupulapayaKadapa\&Nuzvid.
}

\section{Manuscript Info \\ Manuscript History \\ Received: 28 March 2017 \\ Final Accepted: 30 April 2017 \\ Published: May 2017}

\section{Key words:-}

BLAST search, PCR standardization, Sepsis, 16S rRNA, 23S rRNA.

\section{Abstract}

Background: The rapid and accurate detection of bacteremia might have a significant impact in shortening hospital stays within the intensive care unit (ICU) as well as reducing the costs to the health care system. PCR primers targeted to conserved rRNA gene sequences allowed the RNA amplification of virtually any bacterial species.

Objective:The aim of this study is to establish a new diagnostic method to detect bacteremia, using universal primers targeted to $23 \mathrm{~S}$ rRNA and 16SrRNA, directly from blood culture plates.To some extent to address the Nosocomial infections.

Materials \& Methods: Phase I study is doneby doing BLAST search, in which organisms like E.coli, Staphylococcus aureus, Klebsiellapneumoniae, Pseudomonas aeroginosa showed $100 \%$ sequence similarity with the primers targeted to $16 \mathrm{~S}$ and $23 \mathrm{~S}$ rRNA.

Results:Out of 10 samples, five were identified as E.coli, two were identified as Staphylococcus, two were identified as Klebsiella and one was identified as Pseudomonas. All the bacterial colonies gave $16 \mathrm{~S}$ and $23 \mathrm{~S}$ rRNA amplicons of $1404 \mathrm{bp}$ and $896 \mathrm{bp}$ except one sample which was identified as E.coli by biochemical analysis.

Conclusion:The 23S rRNA sequences targeted are conserved, so gave $100 \%$ results upon amplification but the $16 \mathrm{~S}$ rRNA sequences gave only $90 \%$ results when used on same organisms as more heterogenicity was found.

Copy Right, IJAR, 2017,. All rights reserved.

\section{Introduction:-}

Sepsis is defined as an invasion of microorganisms and/or their toxins in the bloodstream, accompanied by the organism's reaction against this invasion ${ }^{1}$. The general public is relatively unaware that sepsis exists, yet it kills approximately $120,000-200,000$ people annually in the United States \& other countries, which is more than the number of AIDS deaths per year all over the world. About $40 \%$ of the people diagnosed with sepsis die, which makes it the leading cause of death in the ICU. In fact, the medical specialty practice of Critical Care Management was specifically developed as a result of septic mortality rates. Sepsis itself is a disease process resulting from an explosive infection that is accompanied by shock if it progresses to the final stage of end-organ damage ${ }^{2}$. The 
interaction of infection and immune response plays a decisive role in the pathogenesis of sepsis. In the process it does not matter if the infection is of bacterial, viral, fungal or parasitic origin. All pathogens can potentially trigger sepsis.It has been estimated that between 400000 and 500, 000 patients are so affected each year in both the USA and Europe. Morbidity and mortality have remained high despite improvements in both supportive and antimicrobial therapies. Mortality rates vary from $40 \%$ for uncomplicated sepsis to $80 \%$ in those suffering from septic shock and multi-organ dysfunction ${ }^{3}$. More than 750,000 episodes of severe sepsis occur each year in the United States, making sepsis the tenth most common cause of death. The average cost per case for treatment of severe sepsis is approximately $\$ 22,000$, and increases with the number of dysfunctional organs. ICUs play a critical role in an AMR emergency because they facilitate a high percentage of patients who are taking extended-spectrum antibiotics.

\section{Sepsis in India:-}

Severe sepsis was common in Indian ITUs (Intensive therapy units). ITU mortality was higher compared to western countries. Gram-positive infections were less common although incidences of parasitic and viral infection were higher than in the West. According to National Neonatal \& Perinatal Database (2002-03) ${ }^{5}$, the incidence of neonatal sepsis in India was 30 per 1000 live-births; Klebsiellapneumoniae and Staphylococcus aureus were the two most common organisms isolated in sepsis cases.

\section{Materials and Methods:-}

Primers used in PCR were designed by using the target sequences from the genes encoding 16S-23S rRNA. PCR was used for the detection of different standard and clinical bacterial strains. The primers used are taken from SIGMA Company.

\section{SF-AGAGTTTGATCYTGGYTYAG}

16SR-ACGGCTACCTTGTTACGACTT

23SF-AGgATGTTGGCTTAGAAGCAG CCA

23SR-CCCGACAAGGAATTTCGCTACCTTA

\section{BLAST Search:-}

Different pathogenic microbes were screened using the above sequences through BLAST search. Only those organisms are selected for present study basing on the high percentage of sequence similarity. The organisms are: E.coli, Staphylococcus aureus, Klebsiella pneumoniae, Pseudomonas aeroginosa, Thermobaculumterrenum, Sphaerobacter thermophillus, Serratia marcescens Streptomyces flavogriseus, Streptomyces pyogenus

\section{Isolation and growth of microbial Cultures:-}

The pure cultures of E.coli, Staphylococcus aureus, Klebsiella pneumoniae, Pseudomonas aeroginosa, are provided by Translational Research Institution of Molecular Sciences (TRIMS) laboratory Visakhapatnam, which regularly maintains the cultures for diagnostic purpose.

\section{DNA Extraction from the microbial Colonies:-}

Microbial colony was taken into a micro centrifuge tube which was containing $100 \mu 1$ of phosphate buffer and centrifuges at 12,000 rpm for 3 minutes. The supernatant was discarded and the pellet was homogenized by finger flicking and the contents were collected into a new $1.5 \mathrm{ml}$ of micro centrifuge tube, and $50 \mu 1$ of $5 \%$ chelax resin $\&$ $2 \mu \mathrm{l}$ of Proteinase K $(10 \mathrm{mg} / \mathrm{ml})$ were added. They were incubated at $56^{\circ} \mathrm{C}$ for 15 minutes and followed by incubation at $100^{\circ} \mathrm{C}$ for 8 minutes. The tubes were centrifuged at $1200 \mathrm{rpm} / 2 \mathrm{~min}$ and the supernatant was collected into new micro centrifuge tube and they were stored at $-80^{\circ} \mathrm{C}$ for further use i.e. for setting up PCR. $2 \mathrm{micro}$ liter of DNA was used to setup PCR.

\section{PCR set up:-}

The PCR with primers $16 \mathrm{~S}$ and $23 \mathrm{~S} \mathrm{~F}$ and $16 \mathrm{~S}$ and $23 \mathrm{~S} \mathrm{R}$ in reaction volume of $20 \mu 1$ was setup. The final concentrations of all the reagents were as follows: 50 mMolarKCl, 10 mMolar TRIS, $200 \mu$ Molar dNTP's, 1.5 mMolar $\mathrm{MgCl}_{2}, 4$ units of TAQ DNApolymerase and 20 pMolar of each primer. The reaction was setup under cycling parameters of denaturation at $94^{\circ} \mathrm{C}$ for 4 minutes, $94^{\circ} \mathrm{C}$ for 30 seconds, $55^{\circ} \mathrm{C}$ for 30 seconds, $72^{\circ} \mathrm{C}$ for 30 seconds and final extension of $72^{\circ} \mathrm{C}$ for 10 minutes. The number of PCR cycles was 35 . After completion of PCR, products were run on $2 \%$ Agarose gel and stained with Ethidium Bromide. 
Table:-

\begin{tabular}{|c|c|c|c|}
\hline S.No & SampleID & $\begin{array}{c}\text { Pathogen identification by biochemical } \\
\text { analysis }\end{array}$ & $\begin{array}{c}\text { Results for 16S \& 23S rRNA broad } \\
\text { range PCR }\end{array}$ \\
\hline 1 & Colony 1 & E. coli & detected \\
\hline 2 & Colony 2 & Staphylococcus aureus & detected \\
\hline 3 & Colony 3 & E. coli & detected \\
\hline 4 & Colony 4 & E. coli & not detected (16S) detected (23S) \\
\hline 5 & Colony 5 & E. coli & detected \\
\hline 6 & Colony 6 & E. coli & detected \\
\hline 7 & Colony 7 & Klebsiella & detected \\
\hline 8 & Colony 8 & Pseudomonas aeroginosa & detected \\
\hline 9 & Colony 9 & Klebsiella & Staphylococci \\
\hline 10 & Colony10 & & \\
\hline
\end{tabular}

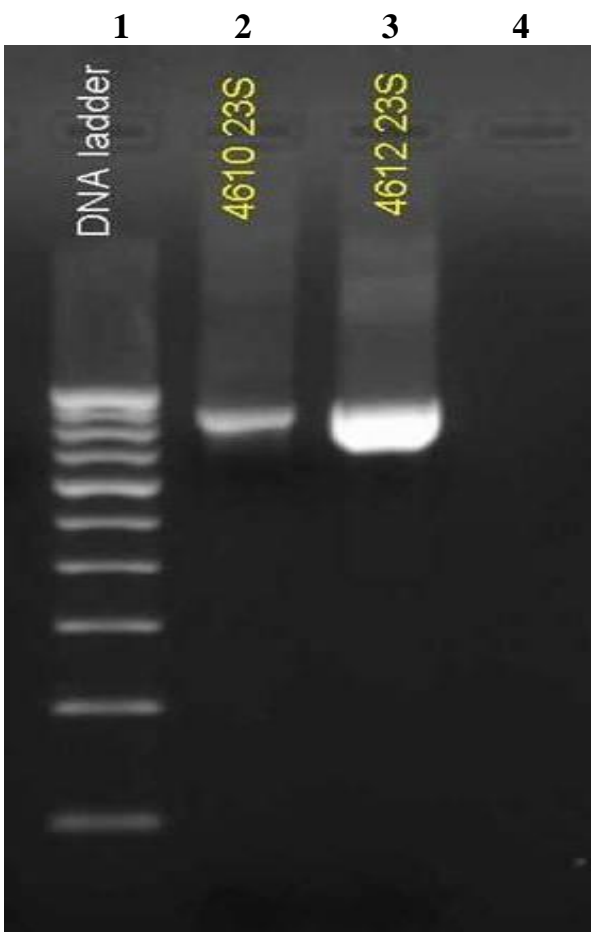

Figure1a:- (23S)
In Fig-1a, lane 1 shows the DNA marker, lane $2 \& 3$ shows 896 bp amplicon size. Lane 3 is PCR subjected from human DNA that served as negative control. 


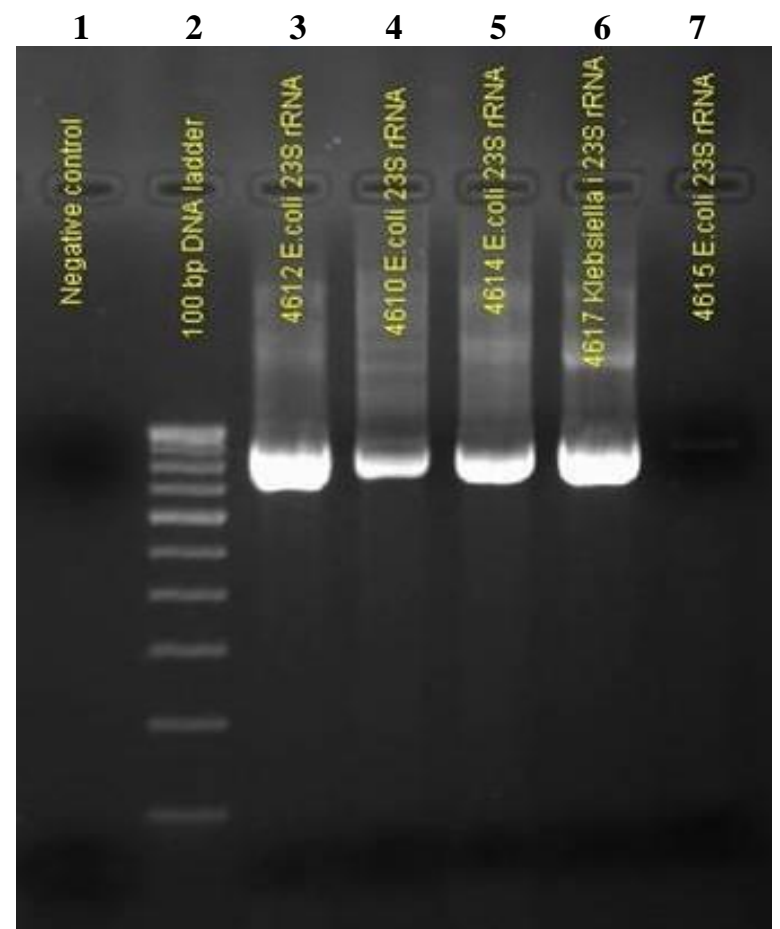

In Fig-2a, Lane 1 is PCR subjected from human DNA that served as negative control. Lane 2 has DNA marker. 3-7 lanes show the bacterial PCR results with 896bp amplicon size.

Figure2a:- (23S)

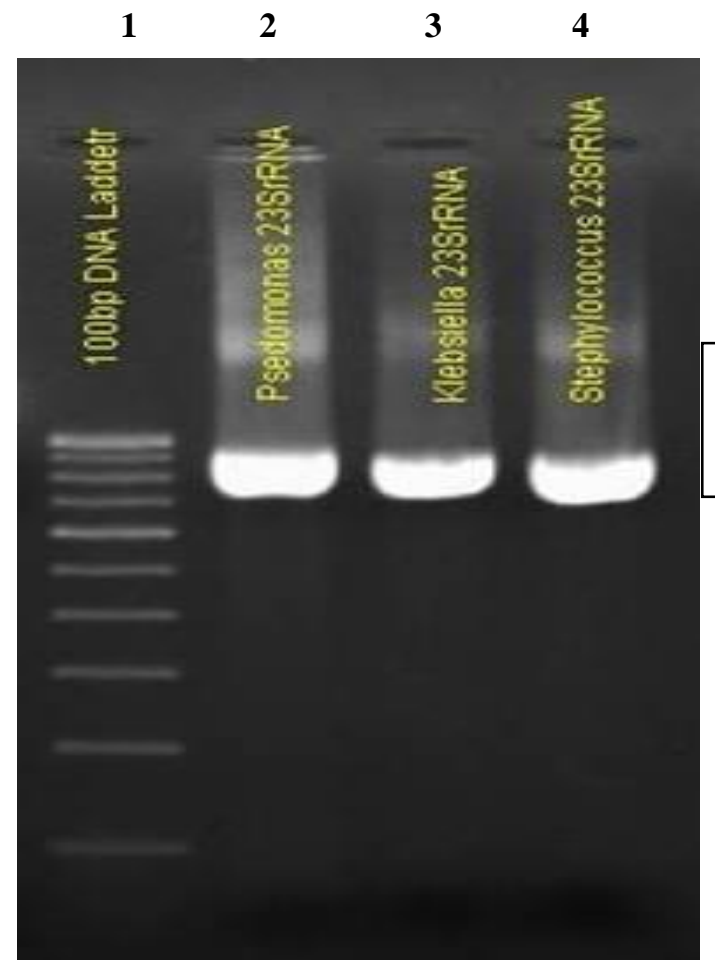

In Fig-3a, shows 2-4 lanes positive for PCR with 896bp representing various bacteria. Lane 1 has DNA marker.

Figure-3a 


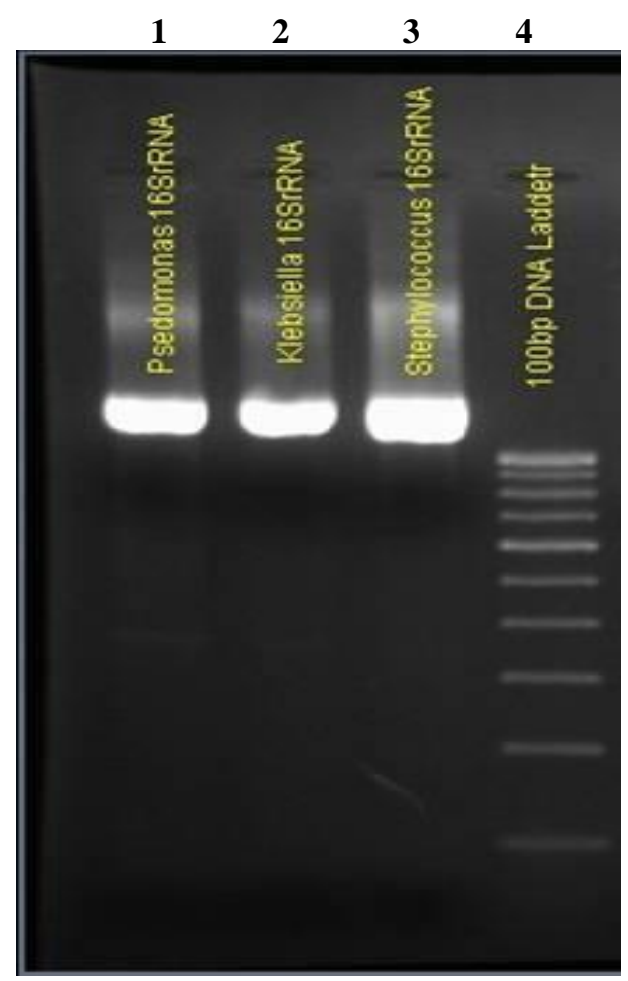

In Fig-1b, lane 4 shows the DNA marker, lane $1 \& 2$ shows 1404 bp amplicon size. Lane 3 is PCR subjected from human DNA that served as negative control.

Figure1:- b (16S)

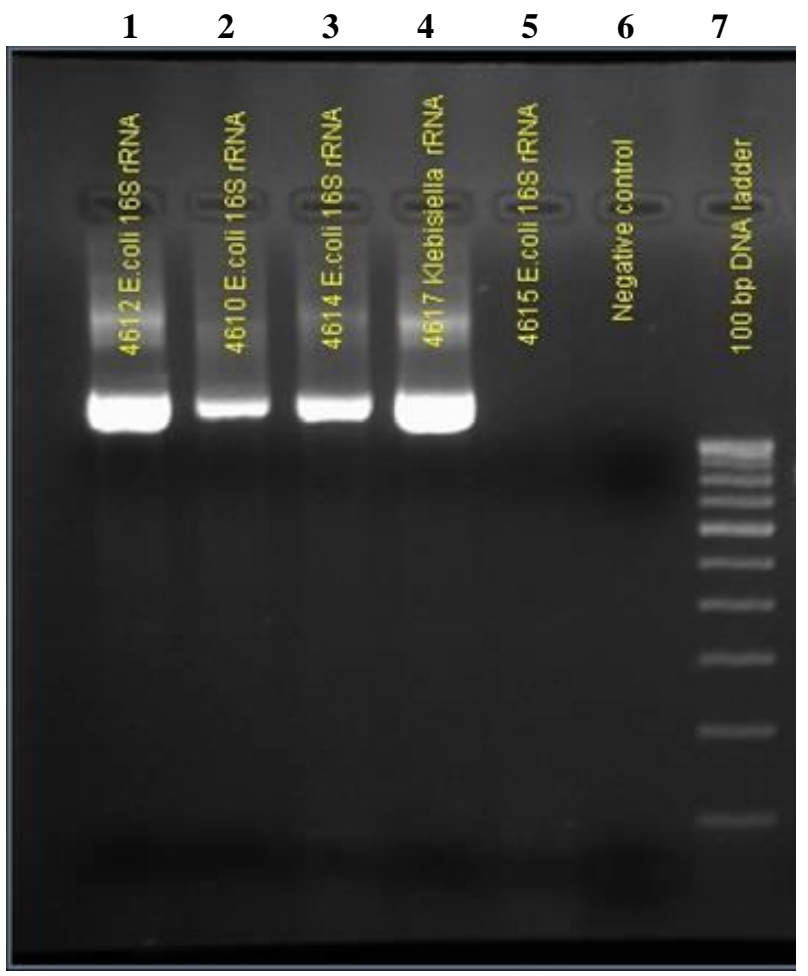

In Fig-2b, 1-4 lanes show the bacterial PCR results with $1404 \mathrm{bp}$ amplicon size.

In lane 5 no band is seen probably it is due to failure of DNA extraction or PCR. Lane 7 has DNA marker.

Figure2:- b (16S). 


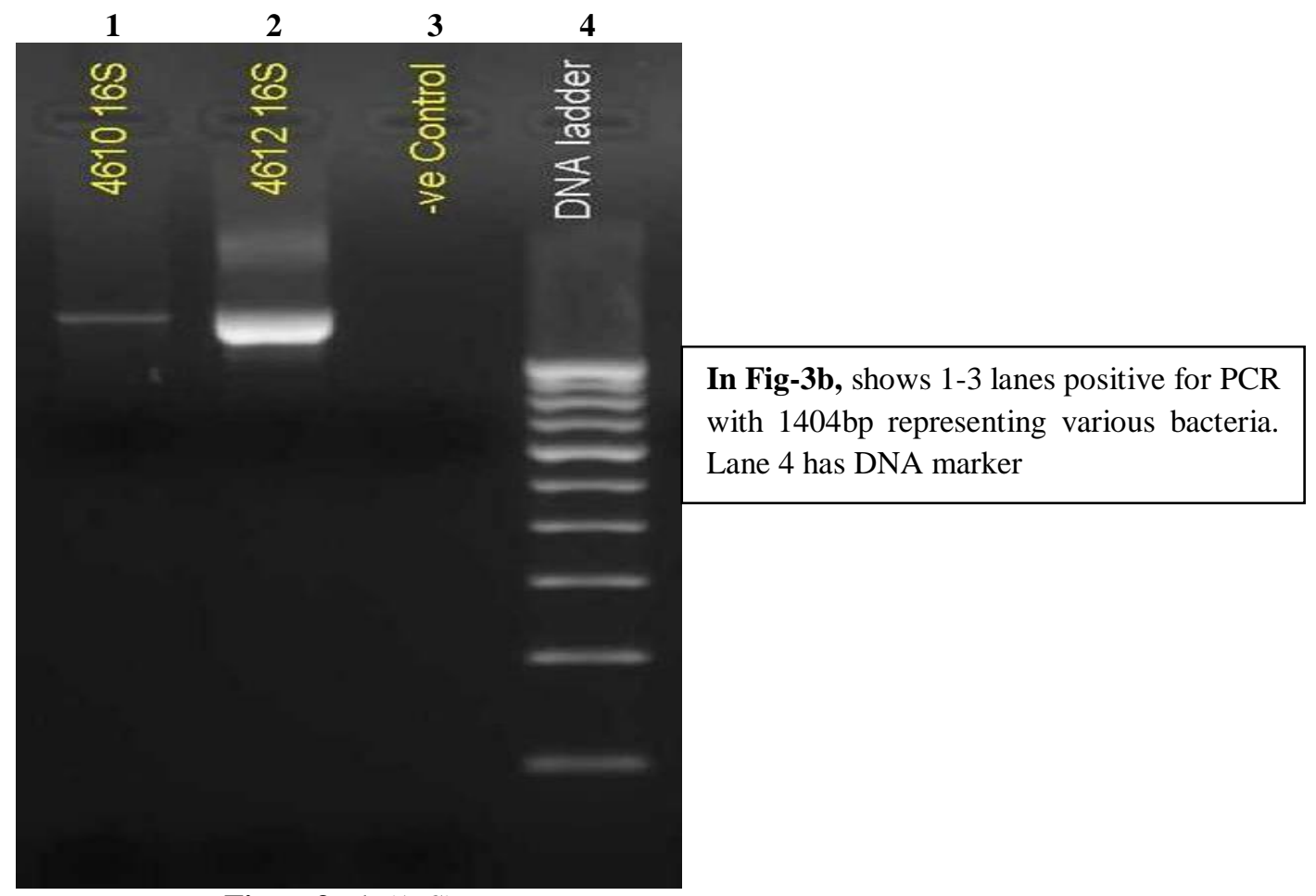

Figure3:- b (16S)

\section{Results:-}

The standardization of PCR for the detection of broad range clinical bacteria targeting 23S rRNA and 16S rRNA sequences was done. The results were tabulated depending upon the gel documentation figures, and are as follows.

\section{Discussion:-}

Severe sepsis and septic shock are important causes of death in intensive care units ${ }^{3}$. Although our understanding of the pathogenesisof inflammation and sepsis has improved, until recently this hasnot translated into clinical benefit. Several new treatment approacheshave given encouraging results. Evidence suggests that the wayforward is to develop pathogen specific regimens rather than assumethat one treatment fits all.

A study published by the Centers for DiseaseControl in the United States indicated that the incidence of septicaemia had increased from 73.6 per 100000 patients in 1979 to 175.9 per 100000 patients in $1987{ }^{4}$. Recent US and European surveyshave estimated that severe sepsis accounts for $2-11 \%$ of all admissionsto hospital or intensive care units.

Although Gram negative infections were predominant in the 1960s and early 1970s, Gram positive infections have increased inthe past two decades and now account for about half of cases ofsevere sepsis. Fungal infections are also increasing in manycountries. Despite better supportive care, the hospital mortalityfrom severe sepsis and septic shock (30\% and over 60\%, respectively)has not changed much over recentdecades.

From the perspective of the physician, early identification of an infectious agent will allow confirmation that infection underlies an inflammatory process, allow the use of efficacious and narrow spectrum antibiotics, and may open the door to new therapies targeted at pathogen-specific inflammatory pathways.

Culture of these bacteria is considered as a gold standard with some limitations such as sensitivity, time-consuming factor and growth failure when antibiotics are used. As a consequent, DNA-based methods have increasingly developed. PCR offers a better approach for rapid detection. Among PCR based methods, multiplex PCR is a good technique which simultaneously detects many targets in a single reaction. 
In Phase I of the project the aim was to standardize 16S \& 23S rRNA broad range PCR to detect various bacteria which cause Septicaemia. The most important bacteria responsible for sepsis in India includes Staphylococcus aureus, Acinetobacter baumanii, Acinetobacter calcoacetius, Pseudomonas aeroginosa, Klebsiella pneumoniae and E.coli. All the colonies which were positive by broad range 16S \& 23S rRNA primers were tested by biochemical assays and morphological characters of genus of the bacteria. The 10 different colonies used in the study were developed from various clinical samplesincluding urine, pus and blood. All the colonies gave correct amplicon of size 1404bp and 896bp products. Only one sample could not be amplified and was identified as E.coliby biochemical analysis. This could be due to an error in DNA extraction or could be due to presence of different bacteria which was not able to recognize by our primers. It needs further investigation to elicit the most probable reason. Excluding the sample the sensitivity of $16 \mathrm{~S} \& 23 \mathrm{~S}$ rRNA broad range PCR is $100 \%$. Including this sample, the sensitivity of $23 \mathrm{~S}$ rRNA is $100 \%$ and $16 \mathrm{~S}$ rRNA is $90 \%$. However, the PCR was done from colonies of bacteria which have got million copies of bacteria. When this procedure is directly applied to the clinical sample the sensitivity might reduce due to low copy no. of bacteria in blood or any other clinical specimens. This procedure further needs to be optimized, for applications in clinical samples against gold standard cultures.

\section{Conclusion:-}

Polymerase chain reaction for the detection of broad range clinical bacteria targeting 23S rRNA and 16S rRNA sequences was standardized, as correct size of amplicon 896bp and 1404bp was obtained.

All the clinical isolates including Staphylococcus aureus, Pseudomonas aeroginosa, Klebsiella pneumoniae and E.coli which are characterized by morphology and biochemical parameters were detected by broad range PCR with $100 \%$ sensitivity with 23 S rRNA and $90 \%$ sensitivity with16S rRNA

The $100 \%$ sensitivity of bacterial isolates detection by 23 SRNA PCR, relative to $90 \%$ sensitivity achieved with 16S rRNA Targeted PCR (details elsewhere) reiterates the more conserved nature 23S rRNA sequences. Probably 23S rRNA sequences are better for detection of bacterial presence and the heterogeneity sequence nature of $16 \mathrm{~S}$ rRNA can be exploited for typing of the bacteria.

\section{Acknowledgement:-}

The Research Guide Dr.Y.V.K.Durga Prasad and his Research Scholars are grateful to the Commissionerate of Collegiate Education Hyderabad for providing infrastructure in the institute to carry out the project work, at the Centre for Research Studies. Dr.V.S.KrishnaGovt.Degree\& P.G. College (Autonomous). Authors are thankful to Principal Dr.V.ChandraSekhar, Dr.V.S.Krishna Govt. Degree \&P.G.College,(A)Visakhapatnam, for providing the necessary facilities during the project work, Dr.J.V.V.S.N.Murthy, former Principal of Dr.V.S.Krishna Govt.Degree \&P.G. College(A) Visakhapatnam for his moral support and encouragement, finally Dr.Jayanthi Undamatala, Scientist, TRIMS Lab, Visakhapatnam for providing pure cultures of bacteria used in the study and for giving her valuable suggestions during the course of our work.

\section{References:-}

1. "Bacteremia and Septic Shock." (2002)The Merck Manual. Section $17 . \quad$ Infections Ch.176.http://www.merck.com/pubs/mmanual_home/sec17/176.html

2. Cheng S, Fockler C, Barnes WM, Higuchi R., "Effective amplification of long targets from cloned inserts and human genomic DNA".(1994) ProcNatlAcad Sci.91:56955699.doi:10.1073/pnas.91.12.5695. PMID8202550.

3. Chamberlain, Neal R., PhD. (2001) "From Systemic Inflammatory Response Syndrome (SIRS) to Bacterial Sepsis with Shock.".

4. Dellinger RP, Levy MM, Carlet JM, et al., for the International Surviving Sepsis Campaign Guidelines Committee. (2008). "Surviving Sepsis Campaign: International Guidelines for Management of Severe Sepsis and Septic Shock: 2008".

5. Hayes TA, (1994). Timmins AC, Yau EH, Palazzo M, Hinds CJ, Watson D: Elevation of systemic oxygen delivery in the treatment of critically ill patients. N Engl J Med, 330:1717-1722.

6. Hesselvik JF, (1991)Malm J, Dahlback B, Blomback M: Protein C, protein S, C4b-binding protein in severe infection and septic shock. ThombHaemost, 65:126-129.

7. Indian Journal of PediatricsVolume 75,Number3,261266,DOI:10.1007/s12098-008-0056-z.

8. Kelley PW. "Leptospira : (1992)In Infectious Disease” Eds. S.L. Gorbach, J.G. Bartlett and N.R. Blacklow, W. B.Saunders Company; 1610-1614.. 
9. Kumar, Vinay; Abbas, Abul K.; (2007)Fausto, Nelson; \& Mitchell, Richard N. Robbins Basic Pathology (8th ed.). Saunders Elsevier. pp. 102-103 ISBN 978-1-4160-2973-1..

10. Lawyer FC, Stoffel S, (1993) Saiki RK, Chang SY,Landre PA, Abramson RD, Gelfand DH. "High-level expression, purification, and enzymatic characterization of full-length Thermusaquaticus DNA polymerase and a truncated form deficient in 5' to 3' exonuclease activity". PCR Methods Appl. 2: 275-287. PMID8324500. .

11. Martin GS, Bernard GR: Airway and lung in sepsis. Intensive Care Med, 27:S63-S79. (2001).

12. Milberg JA, Davis DR, Steinberg KP, Hudson LD: Improved survival of patients with Acute Respiratory Distress Syndrome (ARDS): (1983-1993)

13. Pavlov AR, (2006) Pavlova NV, Kozyavkin SA, Slesarev AI "Thermostable DNA Polymerases for a Wide Spectrum of Applications: Comparison of a Robust Hybrid TopoTaq to other enzymes". in Kieleczawa J. DNA Sequencing II: Optimizing Preparation and Cleanup. Jones and Bartlett. pp. 241-257. ISBN 0-7637-3383-0.

14. Polgreen, Philip M., MD. "Infectious Disease: Sepsis." 10 January (2002). http://www.vh.org/Providers/ClinRef/FPHandbook/Chapter10/05-10.html (25 April 2002.)

15. Phillips, Danny. "KU Med researchers granted sepsis patent." http://www.research.ukans.edu/newsmenu/2000_04/sepsis.html (25April 2002.)

16. Rivers E, Nguyen B, Havstad S, Ressler J, Muzzin A, Knoblich B, Peterson E, Tomlanovich M, Early GoalDirected Therapy Collaborative Group: Early goal-directed therapy in the treatment of severe sepsis and septic shock. N Engl J Med (2001), 345: 1368-1377.

17. Task Force of the American College of Critical Care Medicine, Society of Critical Care Medicine: Practice parameters for hemodynamic support of sepsis in adult patients in sepsis. Crit Care Med, 27:639-660. (1999)

18. Vincent JL: Need for intensivists in intensive care units [commentary]. Lancet (2000), 356:695-696.

19. Vincent JL, de Mendonça A, Cantraine F, Moreno R, Takala J, Suter PM, Sprung CL, Colardyn F, Blecher S: Use of the SOFA score to assess the incidence of organ dysfunction/failure in intensive care units: results of a multicenter, prospective study. Crit Care Med 1998, 26:1793-1800.

20. Ziegler EJ, Fisher CJ, (1991)Sprung CL, Straube RC, Sadoff JC, Foulke GE, Wortel CH, Fink MP, Dellinger RP, Teng NN: The HA-1A Sepsis Study Group. Treatment of gram-negative bacteremia and septic shock with HA-1A human monoclonal antibody against endotoxin. A randomized, double-blind, placebo-controlled trial. $N$ Engl J Med, 324:429-436. 